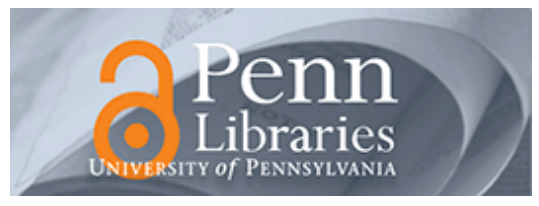

University of Pennsylvania

ScholarlyCommons

Management Papers

Wharton Faculty Research

$3-2002$

\title{
Entry Strategy for Radical Product Innovations: A Conceptual Model and Propositional Inventory
}

\author{
Elisa Montaguti \\ University of Warwick \\ Sabine Kuester \\ New York University \\ Thomas S. Robertson \\ University of Pennsylvania
}

Follow this and additional works at: https://repository.upenn.edu/mgmt_papers

Part of the Management Sciences and Quantitative Methods Commons

\section{Recommended Citation}

Montaguti, E., Kuester, S., \& Robertson, T. S. (2002). Entry Strategy for Radical Product Innovations: A Conceptual Model and Propositional Inventory. International Journal of Research in Marketing, 19 (1), 21-42. http://dx.doi.org/10.1016/S0167-8116(02)00046-0

This paper is posted at ScholarlyCommons. https://repository.upenn.edu/mgmt_papers/275

For more information, please contact repository@pobox.upenn.edu. 


\title{
Entry Strategy for Radical Product Innovations: A Conceptual Model and Propositional Inventory
}

\begin{abstract}
"Takeoff" is a prerequisite for new product success. The central concern of this paper is how firms can reduce "takeoff time" for radical innovations. We propose a set of entry strategies and examine their effectiveness in stimulating initial demand and accelerating time-to-takeoff by considering the moderating impact of technological, competitive and firm-specific factors. The intended contributions are: (1) to enrich the literature on entry strategy by developing a propositional framework from a strategy perspective; (2) to provide managerial guidelines for achieving more rapid takeoff; and (3) to suggest an agenda for research on takeoff strategies.
\end{abstract}

\section{Keywords}

Takeoff time, radical product innovation, entry strategy, diffusion

Disciplines

Management Sciences and Quantitative Methods 


\title{
ENTRY STRATEGY FOR RADICAL PRODUCT INNOVATIONS: A CONCEPTUAL MODEL AND PROPOSITIONAL INVENTORY
}

\author{
Elisa Montaguti, Warwick Business School \\ Sabine Kuester, Stern School of Business, New York University \\ Thomas S. Robertson, Goizueta Business School, Emory University
}

\begin{abstract}
Recent research highlights the managerial significance of new product takeoff. Takeoff is a prerequisite for new product success and reducing time-to-takeoff is a critical issue in the formulation of market entry strategy. The central concern of this paper is how firms can reduce "take-off time" for radical innovations. We propose a set of strategic considerations and specify the determinants of strategy selection for stimulating initial demand. The intended contribution is to enrich the diffusion and technology adoption literature by developing a propositional framework from a strategy perspective and by providing managerial guidelines for achieving more rapid technology take-off.
\end{abstract}

Elisa Montaguti, Assistant Professor, Warwick Business School, University of Warwick, Coventry CV4 7AL (U.K.), +44 2476 522608, fax +44 2476 524628, Elisa.Montaguti@warwick.ac.uk.

Sabine Kuester, Visiting Assistant Professor, Stern School of Business, New York University, 44 West $4^{\text {th }}$ Street, KMC 885, New York, N.Y. 10012-1126, (212) 998 0520, fax (212) 995 4006, skuester@ stern.nyu.edu.

Thomas S. Robertson, Candler Professor of Marketing and Dean, Goizueta Business School, Emory University, 1300 Clifton Road, Atlanta, G.A. 30322-2710, (404) 727 6377, fax (404) 727 0868, Tom_Robertson@ @us.emory.edu.

Key words: Takeoff Time, Radical Product Innovation, Entry Strategy, Diffusion 


\section{ENTRY STRATEGY FOR RADICAL PRODUCT INNOVATIONS: A CONCEPTUAL MODEL AND PROPOSITIONAL INVENTORY}

\section{INTRODUCTION}

The business and trade press constantly herald the arrival of new technologies, such as desktop videoconferencing, digital video-disk, flat-screen television, voice recognition computing, and wireless internet. In such technology-based product categories, marketing managers are faced with a difficult set of intertwined questions, foremost of which are: (1) which of these technologies will actually takeoff, (2) at what speed, and (3) what is the appropriate market entry strategy in order to accelerate takeoff? If answers were available to these questions, they would be key inputs for decisions regarding the deployment of R\&D resources over time and the allocation of marketing funds behind the most promising technologies.

Our concern is with two questions: (1) what entry strategies can be employed to encourage rapid takeoff in order to shorten the risky and resource-intensive market introduction phase and (2) what are the contingencies that influence their strategic appropriateness? These issues are interrelated with the other questions regarding market potential and the projected demand function, but our interest at present is not in modeling or forecasting diffusion. Our goals are to present a conceptual model and propositional framework drawn from literatures in multiple disciplines -- economics, strategy, and marketing -- that identifies the entry strategy that the firm can take to reduce the time to takeoff for a radical product innovation ${ }^{1}$.

\footnotetext{
${ }^{1}$ Radical product innovations have been primarily defined in terms of their technological superiority and their ability to meet customer needs better than prior technologies. In this vein, Chandy and Tellis (1998) define radical product innovations as "innovations that involve substantially new technology and provide substantially greater customer needs" (p.476). Relatedly, Xuereb and Gatignon (1997), in an empirical study show that innovations that encompass a large new body of knowledge tend to have a major advantage over existing products. In this study, we focus on durable radical product
} 
The marketing manager generally wants to accelerate takeoff. This bias may be driven by such objectives as to leverage patents while still valid, leverage competencies before imitated, achieve first mover advantage, or create a critical mass of customers in order to set a dominant standard. However, for radical product innovations there may be some considerable period after launch before rapid diffusion actually occurs. Lehmann (1994), for example, suggests that in the case of the zipper, the time between patenting the technology and successful commercialization was 44 years. Numerous technologies from automated tellers to microwaves to VCRs required over a decade to reach takeoff. The zipper example may constitute an extreme case, but recent studies confirm that takeoff time generally spans many years. In consumer durables, for example, an average takeoff time of 10 to 12 years seems to be the norm (Lehmann 1994; Tellis 1994), although this period is shortening (Tellis 1994; Golder and Tellis 1997).

One managerial implication, given the tortuous diffusion of many radical innovations, is that "...a firm ought to keep early commitments low and make decisions faster" (Moore 1994, p.8). There is a certain logic to this, especially the value of making rapid real-time decisions in an evolving manner as consumer preferences are clarified. However, managers may have to make substantial commitments of resources to "remain in the game" as technology emerges, especially if early mover advantages are likely to be important.

Microsoft is an interesting case-in-point of the need to make resource commitments. It underestimated the potential and the time-to-takeoff for the Internet and lost advantage to Netscape. In order to remain in the game, Microsoft had to make radical changes in its strategy and undertake major commitments to Internet technology. Other firms which did not make adequate and early-enough commitments to radical innovations, such as Barnes and Noble in e-retailing, often have paid a heavy penalty of lower market share and an inability to overcome early mover advantages garnered by firms such as Amazon.

\section{TIME-TO-TAKEOFF}

The process by which a radical innovation acquires initial acceptance has been neglected for the most part in the marketing literature (Mahajan, Muller, and Bass 1990). Bass (1969) models the diffusion of innovation 
assuming that a certain number of consumers have already adopted before the imitation process commences, i.e., N $\left(T=T_{0}\right)>1$. In other words, the Bass model of diffusion assumes that initial takeoff has occurred. This suggests that a critical number of consumers has reached adoption at time $T=T_{0}$ to accentuate the contagion process and to encourage takeoff.

Rogers (1995) argues that the diffusion process begins when a set of innovators, who have higher propensity to engage in trial, adopt an innovation. In this framework, a technology takes off when it passes from the introduction to the growth phase, i.e., when the first inflection-point in the non-cumulative adoption curve is reached.

Despite the managerial significance of this phenomenon, Golder and Tellis (1997) found that many mangers were unaware of its existence as a discrete concept, although most successful consumer durables showed evidence of marked takeoff. Research in this area is also sparse. Golder and Tellis (1997) provide the first empirical study of takeoff. They investigate sales curves for really new household consumer durables for what they call 'elbow-shaped discontinuities' (p.256). They develop a generalizable heuristic to reliably measure takeoff given that product categories are heterogeneous with regard to their base sales. ${ }^{2}$ They find that typically they can identify a takeoff point for new durables and that price and market penetration seem to be strongly associated with it. Agarwal and Bayus (2000) take a different stance when investigating the evolution of both sales for product innovations and industry structure. They find that before sales takeoff, indicated by the 'hockeystick pattern' in the sales history, an increase in the number of firms in the industry occurs. Figure 1 shows some examples of technology takeoffs and Table 1 provides conceptual and operational definitions of the variables that we will pursue.

$$
\begin{aligned}
& \text { - insert Figure } 1 \text { about here - } \\
& \text { - insert Table } 1 \text { about here - }
\end{aligned}
$$

\footnotetext{
${ }^{2}$ Their threshold rule is derived from a plot of the percentage increase in sales relative to a base level of sales which is common across all categories. It performs similarly to the maximum growth rule.
} 
The takeoff concept has some interesting behavioral underpinnings. For example, Padmanabhan, Rajiv, and Srinivasan (1997), in a study about sequential product introductions, demonstrate, that in assessing market potential for new high technology products, firms have access to private information whereas consumers do not. In addition to pre-launch market research, R\&D-marketing integration helps the firm to reduce market uncertainty (Griffin and Hauser 1996; Dutta, Narasimha, Rajiv 1999). When consumers decide about adopting a technology their expectations play a critical role. Uncertainty on the expected size of a future installed base may determine whether a new technology is a success or a failure (Farrell and Saloner 1986a). Once takeoff is achieved market uncertainty is substantially resolved and consumers' expectations regarding the technology are likely to be more favorable than before takeoff.

In a similar vein another interesting behavioral dimension is the categorical shift in consumer problem solving and a major modification in information requirements during the product life cycle. When an innovation passes from the introduction to the growth phase of the product life cycle, consumer choice processes move from extensive to more limited problem solving (Howard 1983), whereby less information and cognitive processing are required. In accord with these ideas, we view time to takeoff as a phase characterized by a high level of market uncertainty and, therefore, of high information requirements. After takeoff, consumers' learning requirements change: uncertainty is reduced and demand becomes more predictable.

In our study we take the vantage-point of managers actively trying to manage the initial stage of the diffusion process. Their objective is to implement entry strategies that can foster initial adoption of a radical innovation subject to the firm's financial objectives and resource constraints and the risk of triggering competitive reactions in order to accelerate time-to-takeoff. The entry strategies that we propose for the purpose of takeoff acceleration will be introduced in the next section.

\section{THE CONCEPTUAL MODEL}

The model proposed is represented in Figure 2. Underlying this model are two fundamental tenets. The first is that the firm's entry strategy can affect the process of preference aggregation occurring at the early stages of the diffusion process (Gatignon and Robertson 1985; Robertson and Gatignon 1986; Arthur 1989; 
Karshenas and Stoneman 1993; Kim, Bridges and Srivastava 1999). In particular, in accordance with the extant literature, we specify a set of strategies that can facilitate early adoption, increase rate of diffusion and, therefore, accelerate time-to-takeoff. The second tenet is that technology, industry, and firm characteristics moderate the selection of strategic actions which the firm pursues to generate initial demand (Kim et al. 1999). As depicted in Figure 2, we focus on the interactions between the entry strategies proposed and these factors.

- insert Figure 2 about here -

\section{Entry Strategy: The Focal Point}

As suggested by Gatignon and Robertson (1991) three major factors determine consumers' adoption decisions. These are (1) awareness, (2) willingness to pay, and (3) product availability. Awareness of an innovation's existence is a necessary condition for adoption. Similarly, adoption takes place only when the difference between the perceived relative advantage of an innovation and the adoption hurdle price hurdle, expressed in terms of price and switching costs and cognitive costs, expressed in terms of learning requirements) is positive. Of course, the customer's expected value of benefits from the innovation potentially increases as more information becomes available and uncertainty is resolved. Price and communication activities influence mainly the first two components of the adoption process. These factors have received a significant amount of attention in the diffusion modeling literature in the past (Parson 1975; Parker 1992; Parker and Gatignon 1996; Parker and Neelameghan 1997). Finally, an innovation must be made available in order for a customer to be able to buy it.

When a firm's objective is to achieve rapid takeoff, customers should be the central driving force of the entry strategy selection process (Howard 1983). This means that a firm's behavior should be designed to best serve early adopters by developing awareness, increasing utilities, reducing uncertainty (Jensen 1982, Chatterjee and Eliashberg 1990) and extending availability. In order to achieve this goal, a firm should reduce the learning

requirement by credibly communicating information about the innovation and intensively supporting entry (Eliashberg and Robertson 1988; Gatignon, Weitz and Bansal 1990). Furthermore, it should position the product to 
demonstrate its clear superiority over existing products, by pricing aggressively or providing a higher customer value (Day and Wensley 1988; Green, Barclay and Ryans 1995; Cestre and Darmon 1998), and it should select the route to market that guarantees the maximum level of innovation availability. In this vein, consistent with Green, Barclay and Ryans' recommendations (1995), we propose the following entry strategies:

(1) follow a penetration strategy, (2) achieve compatibility with existing products, (3) preannounce, and (4) follow an external route to market.

These strategies can be employed as levers to influence the major factors that determine consumers' adoption decisions as mentioned above. In the following we will explain their effect on time-to-takeoff and then address the factors affecting their feasibility.

(1) Penetration strategy entails aggressive pricing and high resource commitments in advertising, sales force and promotional activities. The selection of a penetration strategy is driven by multiple factors. First, the objective of this strategy is to attract a critical mass of adopters, thus, to stimulate demand through a diffusion effect (Kalish 1988). Secondly, penetration strategies are selected in order to benefit from cost reductions via learning effects (Dean 1969; Robinson and Lakhani 1975). Finally, the choice of a penetration strategy is a preemptive move to discourage other competitors from taking an equally strong stance toward the target market.

Penetration strategies are generally compared to skimming strategies, which are focused sequentially on particular segments of customers. Skimming strategies allow the firm to price discriminate throughout the product life cycle. The classic notion of Bain (1956) was to "skim the cream" by charging high prices initially to price insensitive customers and then reducing price in a stepwise manner over time to bring new segments of customers into the market.

Penetration strategy at the consumer level is apt to a) create high awareness about the technology, i.e., the prerequisite for any adoption decision, and b) to increase consumers' willingness to pay by lowering the price hurdle (Gatignon and Robertson 1991; Kim and Mauborgne 2000). Penetration strategy, therefore, tackles two important factors in the consumers' adoption decision process and constitutes a potentially powerful tool in 
takeoff acceleration. However, penetration strategy is not always feasible and we examine under which circumstances a penetration strategy is traded for a skimming strategy.

(2) Compatibility. When a radical innovation is launched, its value is affected by the amount of information available but as well by product features (Xie and Sirbu 1995). The pursuit of compatibility may allow the firm to achieve superior positioning, since consumers accrue value to the possibility to access a larger network, or to assemble a product system that is closer to their ideal configuration (Matutes and Regibeau 1988; Gandal 1994; Economides and White 1994). Similarly, compatibility eliminates the uncertainty related to the dominant customer base. By contrast, launching a technology which is deliberately incompatible with an existing installed base, or with existing products, may retard market acceptance and alter the competitive dynamics as early adopters may postpone their purchases when they have uncertain expectations about the network which will prevail. Compatibility will influence positively consumers' evaluation of an innovation's relative advantage and, hence, their willingness to pay (Gandal 1994). It is another important decision that affects technology takeoff under conditions which we will seek to specify.

(3) Preannouncing conveys information and increases awareness about a forthcoming innovation. In doing so, it can facilitate the creation of an installed base by potentially reducing customers' costs of adopting an innovation and by ameliorating information asymmetries between the firm and its customers. In this study, we focus on the impact of preannouncing on consumers' expectations about a radical innovation. We recognize that preannouncing behavior is also driven by competitive rationales designed to discourage rivals from following the firm's lead (Robertson, Eliashberg, and Rymon 1995; Bayus, Jain, and Rao 1997). However, the latter is not our focus and earlier research by Eliashberg and Robertson (1988) has documented that the vast majority of external preannouncements are to customers and not for competitive purposes. Preannouncing may have two effects on consumer adoption decisions: 1) it provides pre-launch information and creates awareness in the targeted market segment and 2) it may help reduce uncertainty and increase willingness to pay (Farrell and Saloner 1986a). Hence, preannouncing may help a technology to takeoff faster under certain conditions, which we will specify.

(4) External Route to Market. 
Rapid innovation availability is critical in order to achieve quick takeoff. The route to market for a radical innovation can be a key management decision variable. The previous assumption in most of the diffusion literature was that an innovation is available if the consumer is ready to buy. This is, of course, not necessarily a valid assumption and, increasingly, researchers are addressing the role of distribution in the diffusion of new products (e.g., Jones and Mason 1990; Jones and Ritz 1991; Gatignon and Anderson 1998).

The difficulty is that firms often miss the necessary competencies and resources to commercialize radical innovations (e.g. distribution access, service capability, customer relationships). The firm's options may be limited, therefore, to the resource-intensive and time consuming creation of its own salesforce (internal route) or the formation of marketing alliances - under certain conditions- sometimes on a horizontal basis with other manufacturers (external route). The latter may help firms to more rapidly acquire the complementary assets needed to bring such innovations to market while increasing availability and customer value (Teece 1992; Tripsas 2000). Relatedly, Hultink et al. (1998), in their empirical analysis suggest that radical product innovations tend to be launched through new distributors.

\section{DETERMINANTS OF ENTRY STRATEGY TO REDUCE TAKEOFF TIME}

Despite the potential preference for pursuing penetration, compatibility, preannouncing, and external routes to market to facilitate early adoption, prior work indicates that other factors outside the direct control of management influence the entry strategy selected. For instance Gatignon, Weitz and Bansal's findings (1990) indicate that market characteristics affect the level of marketing support at entry. In a similar vein, Kim, Bridges, and Srivastava (1999), in an empirical study on the relationship between changes in demand and competitive entry, find that the industry's competitive intensity is a primary driver of a firm's entry strategy mode. Furthermore, Green, Barclay, and Ryans (1995) argue that sources of advantage influence the level of marketing effort devoted to a radical innovation launch. 
Relatedly, we contend that firms' propensity to pursue strategies to achieve rapid takeoff is influenced by the contingencies that affect such strategies' marginal returns as well as marginal costs. In particular, based on the existing literature, we contend that the firm's incentives to pursue an entry strategy to foster early adoption are moderated by three broad categories of factors. These are (1) technological characteristics (Xie and Sirbu 1995; Padmanabhan, Rajiv and Srinivasan 1997), (2) the competitive environment (Kim, Bridges and Srivastava 1999), and (3) firms' sources of advantage (Gatignon and Bansal 1990; Green, Barclay and Ryans 1995). The conceptual model (Figure 2) explicates the moderating effects of these factors, which we will now discuss.

\section{Technological characteristics}

In this study we examine the impact of exogenous factors, which increase or reduce the firm's incentives to pursue takeoff-accelerating strategies. The nature of the new technology affects the menu of possible actions to be considered by the firm (Kotabe, Sahay and Aulakh 1996). As indicated in Figure 2, we examine the effects of network externalities and technology appropriability on the firm's strategic actions. These two factors are dominant in the economics literature on innovation.

\section{Network externalities}

Technology based innovations, such as Internet, fax, and desktop video conferencing require a "critical" number of adopters in order to be effectively used. Their utility is an increasing function of the number of people they network. In a similar vein, the number of users of a new technology may influence the availability of future applications (software) or the creation of technological infrastructures. This suggests that consumers ascribe a value to the size of the actual or potential network of subscribers. We may think of externality as an effect which occurs whenever the "utility that a given user derives from a good depends upon the number of other users who are in the same "network"' (Katz and Shapiro 1985, p.424).

The externality effect has attracted a good deal of interest in various fields, such as industrial economics (Rohlfs 1974; Katz and Shapiro 1985; Farrell and Saloner 1985; Choi 1994), strategy (Wade 1995) and marketing 
strategy (Esser and Leruth 1989; Kotabe, Sahay and Aulakh 1996). Recently, some notable attempts have been made to validate this construct empirically. In an analysis of the computer spreadsheet market, Gandal (1994) tests whether this technology exhibited network externalities. The estimation of a hedonic price equation shows that compatibility with a dominant installed base increases consumer utility, providing evidence of a positive role of network externalities. Brynjolfsson and Kemerer (1996) have extended Gandal's work by incorporating unit sales and market price data. Their results are consistent with the previous research effort and show the positive effect of the installed base on consumer utility. In a different vein, Saloner and Shepard (1995) assess the effect of network externalities on the adoption of automated teller machines (ATMs) by banks. By considering the number of branches that a firm has as a proxy for the expected network size, the authors find network size increases the probability of early adoption.

The presence of network externalities has important consequences on both the demand and supply sides. On the demand side, direct or indirect benefits induce consumers to make decisions conditional on other consumers' adoption decisions. Consumers are encouraged by network benefits to prefer the adoption of a "dominant technology" to one which they might individually prefer, since dominant products tend to be supported by a wide variety of services (Chou and Shy 1990). The presence of network externalities might encourage customers to delay adoption until the uncertainty concerning the network that will prevail is alleviated (Farrell and Saloner 1985). Alternatively, the customer faces the possibility of being stranded when other people adopt a different and incompatible technology (Choi 1994).

The effect of network externalities on the demand side is such that multiple equilibria may exist and the process of preference aggregation occurring at the initial stage of diffusion is a critical determinant of the final success of a new technology (Granovetter 1978; Arthur 1989; Cabral 1990). In other words, the success of a radical innovation in the presence of externalities is influenced fundamentally by events occurring early in the diffusion process. Therefore, the ability to gain a critical mass of early adopters and the speed at which this task is accomplished (Katz and Shapiro 1986b) become crucial factors for a technology to diffuse successfully. 
The presence of externalities has important implications on the supply side as well. In the presence of network externalities, time-to-takeoff depends on how quickly the uncertainty among customers regarding the dominant design that will prevail is alleviated. As a result, the entry strategy should consider the extent to which each strategy dimension contributes to a reduction of such uncertainty. Penetration strategies have a particular value in markets with network externalities. The ultimate objective is to reach early adopters' reservation prices sooner and, therefore, to accelerate their adoption. Dhebar and Oren (1986) examine optimal pricing policy for a monopolist to follow for a technology characterized by network externalities. Their results suggest that an increasing, then decreasing price path, should be followed in order to subsidize early adopters for the excessive costs which they bear due to incompatibility with existing installed bases.

Analytical models also have shown that the appropriate introductory price allows a new entrant to legitimize a new technology faster. For instance, Cabral, Salant and Woroch (1992) argue that the monopolist wants to set a price schedule such that a "medium valuation customer" prefers to adopt the new technology in the initial stage. More recently, Economides and Himmelberg (1995), in an empirical analysis of the fax market, show that rapid expansion of the network is associated with low, then increasing prices, even when marginal costs are decreasing over time (Economides 1996). The same recommendation emerges from Xie and Sirbu (1995). Their study examined the dynamic price behaviors of both a new entrant and an incumbent. They found that an increasing and then decreasing price is the optimal price trajectory in a monopoly and oligopoly, when network externalities are strong. Therefore, in the presence of network externalities, we would expect that a low initial pricing policy would be adopted. We would also expect that the firm would commit extensive marketing resources to accelerate adoption.

From the previous discussion it becomes evident that a high level of uncertainty about the installed base may delay consumer adoption and takeoff for radical innovation. Technology compatibility plays a critical role in consumer adoption decisions. In situations characterized by a high level of uncertainty, the probability that firms seek compatibility is high (Katz and Shapiro 1985, 1986a). Following a game theoretic approach, Katz and Shapiro (1985) examine the optimal strategies of new entrants with regards to compatibility. They show that 
private incentives to achieve compatibility are low when a firm has a large installed base and a strong reputation. In a not dissimilar manner, the same authors further explore this topic in a two-period game and industry evolution (1986a). By analyzing a duopoly market with homogenous consumers and where marginal costs are known, they study the compatibility decision as a function of the firm's relative cost advantage and installed base. They find that the firm, which holds the cost advantage in the first period, but is overtaken in the second period, always prefers compatibility, whereas the other firm, which holds the cost advantage in the second period may or may not prefer compatibility.

In this vein, Esser and Leruth (1989) argue that a joint move among technology providers increases the probability of imposing a standard. In particular, when the unilateral enforcement of a dominant design is difficult, or when a standard battle would slow the rapid and successful diffusion of a radical innovation, the benefits of standard-setting alliances increase. In markets not subject to network externalities, there will be less pressure to achieve a single design in order to accelerate takeoff. In fact, consumers may prefer variety (Katz and Shapiro 1986a) and multiple standards may be possible. However, under network externalities, the relative attractiveness of competing technologies to the consumer is affected both by prior sales and by expectations of future sales. In effect, according to Katz and Shapiro (1985), there are "demand-side economies of scales". When compatibility is achieved, competition is then redirected toward more conventional dimensions, such as price and marketing variables (Besen and Farrell 1994). In other words, by pursuing compatibility, firms eliminate network rivalry, without, of course, eliminating other aspects of competition.

Network externalities may also have an influence on the appropriateness of preannouncing. One dominant rationale for preannouncing, for example, is when faced with a large installed base of the previous technological solution. According to Farrell and Saloner (1986a), the installed base may constitute a barrier to entry. However, when there are significant network externalities, the timing of the announcement of a new incompatible product can crucially determine whether the new product supersedes the existing technology. This results from both a reduction in sales for the existing technology, if consumers decide to wait, and an increase in sales for the new technology due to pent-up demand. 
Of course, other factors also influence the likely success of preannouncements, such as the credibility and level of commitment demonstrated by the preannouncing firm (Robertson, Eliashberg and Rymon 1995; Bayus, Jain and Rao 1997). Evidence of credibility, for example, might be whether the firm names a set of lead customers, which is a means to develop indirect externalities. The existing incumbent might also preannounce to protect the installed base, as Microsoft successfully did against IBM's OS-2 operating system software. In a more current scenario, Nintendo and Sony preannounced next generation video game systems as a countermove to industry novice Microsoft's announcement to enter this market with a product called Xbox. Ultimately, the consumer's evaluation of credibility and commitment determines the success of competing announcements. Credible preannouncing can reduce customer uncertainty and facilitate demand coordination and, thus lead to more rapid takeoff.

The necessity to acquire rapid market acceptance places a premium on immediate market access. This mitigates against the firm creating a new salesforce or against the use of its existing salesforce unless appropriate expertise exists. Under conditions of network externalities, these pressures are accentuated due to the need to create a dominant standard quickly. Marketing alliances or licensing are the natural outcomes of these pressures, as for example Blackberry in the handheld internet market. The firm aligns with distribution partners to acquire complementary assets allowing rapid market coverage -- salesforce and marketing expertise. These partners may also be critical in achieving a total systems solution, if the new technology must fit as part of a broader solutions package for the customer. When the products within a system (such as a computer system consisting of CPU, software, printer, modem, etc.) are made by different vendors, not only might design alliances be necessary but marketing alliances might be needed to engage in a total system sale (Morris and Ferguson 1993). The interdependence of products in many technology systems means that marketing strategy is often bound to the product's role in conjunction with other products (Hakansson and Snehota 1989). The level of uncertainty surrounding a radical innovation also has important consequences on the willingness of the launching firm to commit to irreversible investments, such as creating a new distribution system when the existing one does not have the necessary customer access expertise. 
Findings about the relationship between network externalities and entry strategy can be summarized as:

P1 The higher the network externalities, the greater the likelihood of: (1) a penetration strategy, (2) product compatibility, (3) preannouncing, and (4) the use of an external route to market to reduce time-to-takeoff.

\section{Appropriability}

The second technology-related factor that we consider (Figure 2) is appropriability. Appropriability refers to the attributes of an innovation that allow the firm to capture profits from its innovative activity. Teece (1986) suggests that low appropriability encompasses innovations which are difficult to protect because they can be easily codified and/or legal protection mechanisms are ineffective. High appropriability includes innovations, which are easy to protect because knowledge about them is tacit or they have legal protection.

The most obvious basis of appropriability would seem to be patents. However, the relevance of patents varies considerably for different technological domains. Taylor and Silberston (1973), for example, documented the "strong and pervasive influence" of patents in pharmaceuticals and specialty chemicals but not in basic chemicals, oil refining, or electronics. Mansfield (1986) found the pharmaceutical industry to rely most on patents, whereas industries such as instruments and office equipment attached little significance to patents. The variation in the value of patents as a form of appropriability, according to Geroski (1995), is a function of three factors: (1) the ability of imitators to "invent around" a patent, (2) the ease of actually delineating a patent, and (3) the fact that patent filings can actually disclose enough information to allow imitators to develop variants. In pharmaceuticals, for example, firms engage teams of lawyers to monitor constantly FDA patent applications as part of their competitive intelligence system. If patents are not always a means of providing appropriability, what other means are available to the firm? The distinction drawn in the marketing literature (Kotabe, Sahay and Aulakh 1996) is between appropriability regimes based on the legal enforcement system versus regimes based on learning curve, lead time, and the independent ability of other firms to develop a similar technology concurrently.

This definition builds on work by Levin et al. (1987), who studied methods of appropriating the benefits of innovation across a cross-section of R\&D executives. Results indicate that first mover advantage, learning curve advantage, and superior sales or service are more important than patents in achieving appropriability benefits. For 
process innovations, secrecy was also more important than patent protection. Only in pharmaceuticals and certain specialty chemicals did patents achieve prominence.

We now examine the impact of appropriability (however achieved) on the mix of strategic actions that the firm will pursue to accelerate time-to-takeoff. We believe that appropriability will be a key variable influencing the firm's behavior at the early stages of commercializing a radical innovation. How does appropriability affect the likelihood of adopting a penetration versus a skimming strategy? Under conditions of high appropriability, the firm has the discretion of whether to pursue skimming or penetration. However, our expectation is that high appropriability is associated with a penetration strategy under the assumption that the firm's objective is to minimize time-to-takeoff. Skimming strategies may be preferable to maximize short-run profitability but they assume an absolute confidence in the appropriability regime and would seem to apply mainly for stand-alone products not subject to issues of standards and network externalities. Given that it is not our intent to specify interactions, we will pursue only the dominant conclusion that strong appropriability favors penetration.

The logic for this relationship is that a penetration strategy requires protection from rapid competitive imitation. Under high appropriability the innovating firm can seize market initiative to accelerate customer acceptance without running the risk of new entrants eroding its potential returns. If appropriability is weak, the firm runs the risk that its investments in customer education and demand creation will be expropriated by other firms. By the same token if the firm, under high appropriability conditions, were to pursue a skimming strategy (high pricing, segmentation, limited marketing allocation), it would deplete its appropriation advantage over time and allow imitators to enter before it had moved down the demand elasticity curve to reach broader market segments. In effect, penetration pricing or limit pricing strategies are most likely to discourage the entry of potential rivals (Scherer and Ross 1990).

Under conditions of low appropriability, by contrast, the firm has little discretion to pursue a penetration strategy since its investments will not be protected. It runs the risk of the hazard of expropriation (Pisano 1990). Therefore, its most likely option is to pursue a skimming strategy to a limited niche within the market, to limit its investment, and to recognize that imitation is inevitable (Nascimento and Vanhonacker 1988). This can, for 
example, be observed in flatscreen TVs, a slowly evolving oligopolistic industry in which a handful of players deploy skimming because competitive imitation is

inevitable. ${ }^{3}$

The degree to which a radical innovation is protectable influences the firm's propensity to make the technology compatible with an existing installed base. A strong appropriability regime allows the firm to enforce its technology (Teece 1988) and gives it the discretion of incompatibility. The selection of compatibility becomes more critical when it entails information disclosure, which may place advantage rights at risk. For instance, Apple contended that the disclosure of the necessary information to release a compatible standard would have marred its property design (Economides and White 1994). A similar logic prevails at Intel where protection of intellectual property is a key strategy component. Therefore, although compatibility can foster adoption and takeoff by reducing learning and switching costs, we argue that the incentive for compatibility is reduced in the presence of strong appropriability regimes (Besen and Farell 1994).

In a similar vein, signaling entry has the potential to accelerate time-to-takeoff by increasing consumers' awareness. A major risk, again, however, is in cueing competitors as to the firm's future actions and giving competitors greater time to respond (Heil and Robertson 1991). The ability to signal (preannounce) suggests the concurrent ability to protect via barriers to entry. Appropriability constitutes a protection barrier which gives the firm the ability to achieve preannouncement benefits without the risk of inducing competitive response in the short run. The reverse logic is that secrecy (as opposed to preannouncement) may be the means of protecting the technology when appropriability is weak. Levin et al. (1987) found secrecy to be particularly important for process innovations, which, as suggested, are less subject to patent protection. Hiding the innovation is the antithesis of public preannouncements.

\footnotetext{
${ }^{3}$ Of course, the reader might observe that cause and effect could be in dispute in that penetration strategies might be used to create a level of appropriability based on lead-time and learning curve advantages as documented in the Levin et al. (1987) study. That is, if patents can be imitated, then perhaps speed of entry is a potential advantage (Mansfield 1985). Nevertheless, we would argue that it is appropriability that drives the selection of strategy and not the reverse.
} 
As alluded to above, a strong appropriability regime allows the firm to extract rent from other parties while minimizing the risk of expropriation. Of course, this places the firm in an advantageous position to acquire externally the necessary resources to make a radical innovation rapidly available to its customers. Given the objective to minimize time-to-takeoff, therefore, the firm under high appropriability conditions will be likely to form collaborative and contractual links with external sources to access a broad profile of markets. By contrast, under a weak appropriability regime, the risk of expropriation due to the inability to define and enforce intellectual property is too high. As a result, the incentive to increase availability via market contracts is reduced. To summarize, the general thesis is that:

P2 The higher the appropriability of the technology, the greater the likelihood of (1) a penetration strategy, (2) new product preannouncements, (3) the use of an external route to market, but the lower the likelihood of (4) product compatibility to reduce time-totakeoff.

\section{Competitive environment}

At entry, the management propensity to foster early adoption is influenced also by competitive factors that are outside its control. These include the structural characteristics of the industry, such as industry competitiveness, and barriers to entry. In particular, we examine the level of industry concentration and the level of incumbency. The former captures the level of concentration among firms in an industry, whereas the latter captures the existence of an installed base and the effect on selection of strategies to accelerate time-to-takeoff.

\section{Industry concentration}

The number of competitors affects the level of expected cooperation and, hence, the level of competitive rivalry (Scherer and Ross 1990). Research in industrial organization, for example, suggests that rivalry tends to intensify as the number of competitors increases and as they become more equal in size and capability. Similarly, Moore and Moore (1990) show that rates of cooperation are lower as the number of subjects that participate in 
an interaction increases. From these arguments we can infer that the lower the level of industry concentration, the higher the level of competitive intensity.

Our interest is in examining the direct effect of industry concentration on strategy selection and, in particular, how the number of actual and potential players competing in the early stage of an innovation's life cycle influences the manner in which market acceptance is pursued (Dolan, Jeuland and Muller 1986). Of course, industry concentration for radical innovations is a somewhat nebulous concept. The rapid changes, including introduction of rival technologies, characterizing the early stage of a radical innovation life cycle may modify the industry structure. However, we contend that the release of a new technology is not necessarily associated with a complete redefinition of the industry profile. One example is the DVD industry. Players in this globally emerging product category come from the established pool of consumer electronics firms.

Under conditions of high competitive intensity, greater resource allocations and more aggressive pricing policies are likely to occur, thus encouraging rapid takeoff (Brown 1981; Robertson and Gatignon 1986). Eliashberg and Jeuland (1986) have shown, for example, that prices decrease after a new entry and that demand increases as a result of price sensitivity.

Nevertheless, the diffusion modeling literature is not consistent in its recommendations concerning dynamic pricing strategies to foster rapid diffusion of new durables under different levels of industry concentration. Results vary with the specification of demand functions. For instance, Robinson and Lakhani (1975) show that when the word-of-mouth effect is assumed to be the primary force driving new product acceptance, a penetration price is found to be the optimal strategy for the monopolist (see also Dolan and Jeuland 1981; Kalish 1983; Horsky 1990). A similar result was obtained by breaking down the process through which an innovation spreads into two components: a demand saturation effect (whereby demand decreases as cumulative demand increases) and a diffusion effect (whereby demand increases as cumulative demand increases) (Rao and Bass 1985). Whenever the demand saturation effect is dominant, a skimming price strategy is recommended; by contrast when the diffusion effect is dominant, a penetration price is suggested. 
Results obtained in the oligopoly case have been shown not to differ from the monopoly case when the diffusion effect is dominant. However, the incumbent's expectations on the timing of a rival's entry have been shown to affect the "aggressiveness" of the penetration strategy (Eliashberg and Jeuland 1986). The lack of consistency of results and the lack of a strong conceptual argument cause us not to specify an expectation regarding industry concentration and the value of a penetration versus skimming strategy.

Incentives to achieve product compatibility decrease if the industry in which a radical innovation is introduced is characterized by a limited number of players. Each may seek to impose its own standard, hoping to reap the rewards of creating the industry's dominant design. As the level of market concentration and the market power of each competitor increases, the probability that a firm is in the position to enforce its own standard and initiate a "bandwagon of innovation" increases (Axelrod et al. 1995). Hence, the incentives to engage in a "winner-takes-all" race are higher compared to the incentives to develop a standard-setting alliance or to manufacture products, which are compatible to those of a rival. In fragmented markets, by contrast, the need for coordination (e.g., through standard-setting alliances) is stronger, since the presence of various technologies may prevent or retard the emergence of a "market generated" de facto standard (Farrell and Saloner 1986a). This, of course, increases a firm's incentives to pursue compatibility.

Industry concentration is also expected to influence the intensity of preannouncing for radical innovations. When industry concentration is low, the risk of rivals' reactions to a firm's preannouncement is limited, since each competitor is too small to secure profitability by rapidly matching preannouncements. Thus, the firm may gain through preannouncing by allowing consumers to engage in advance planning for changeover.

In more concentrated markets competitors can monitor their rivals more carefully. This reduces the benefits and the incentives to preannounce. It should be noted that empirical research on reaction to entry has not found industry concentration to be a significant predictor of reaction intensity within oligopolistic markets (Robinson 1988a; Bowman and Gatignon 1995). However, in their study of retaliatory behavior to new product entry Kuester, Homburg, and Robertson (1999) found that industry concentration had a significant negative effect on product retaliation, reaction speed, and breadth of reaction. The finding regarding reaction speed is consistent 
with Chen and MacMillian (1992), who studied the oligopolistic airline industry. Perhaps incumbents in more concentrated industries try to avoid aggressive conduct because the likelihood of a significant share loss is prevalent. Also, literature on strategic groups suggests that in markets with a large number of competitors, the number of relevant competitive parameters increases (e.g., Kim and Lim 1988). Thus, we anticipate preannouncing to occur in less concentrated industries.

The lower the industry concentration, the lower the probability that a single player has the skills and the marketing resources that are necessary to rapidly penetrate the market for a radical innovation. This increases the incentives to acquire complementary marketing assets externally, which are necessary for the commercialization of a radical innovation (Teece 1992).

P3 The higher the industry concentration, the lower the likelihood of (1) compatibility, (2) preannouncing, and (3) the use of an external route to market to reduce time-to-takeoff.

\section{Level of incumbency}

Industries in which a radical innovation is introduced are likely to be comprised of some range of new entrants (generally start-up firms rather than firms from other industries) and incumbents; i.e. firms that participated in the previous technology. For our purposes we will think of three ideal types of industry configuration for radical innovations: (1) industries represented only by new entrants (2) industries represented by a mix of incumbents and new entrants, and (3) industries represented only by incumbents.

Incumbency captures the impact of the existence of an installed base on firms' conduct to accelerate time-to-takeoff. An installed base forms an entry barrier to firms considering the launch of a radical innovation due to a reduced customer willingness to switch to a new technology (Gilbert 1989). Furthermore, an installed base does not necessarily correspond to the market share of each incumbent as more than one player can compete within the same technological specification (e.g., GSM mobile phone providers or Intel Pentium III micro-processors). By abandoning a technology with an established installed base, a customer incurs the costs of converting, such as those arising from the need to unlearn how to use the previous technology and to learn how to use the new one (Dhebar 1995). In other words, customers have to sustain high switching costs due to their 
commitment to the previous technology (Klemperer 1987; Heide and Weiss 1995). It is our thesis that the level of incumbency characterizing the industry into which the radical innovation is launched is a key determinant of the strategic actions taken by firms in that industry.

The literature is unified in specifying the relationship between the installed base and the likelihood of penetration pricing strategies for existing technology players. The dominance of incumbent firms is often reflected in temporary price reductions for an existing technology to act as a barrier to entry against new entrants with a new technology (Farrell and Saloner 1986a). In this situation incumbents may deter entry via penetration strategies in order to protect the revenue stream generated from the installed base. ${ }^{4}$

As alluded to above, in a market characterized by a high level of incumbency, incumbents generally will seek to increase the commitment to the status quo and, therefore, to promote standards compatible with their previous installed base (Cooper and Schendel 1976). This generally leads to sub-optimal design of the new technology and it is unlikely to be a successful long-run strategy (Cooper and Schendel 1976; Tushman and Anderson 1986). Conversely, when the industry contains primarily new entrants, firms tend, ceteris paribus, to choose incompatibility with their rivals, since they have high incentives to create their own installed base. Finally, when the industry consists of a mix of incumbents and new entrants, the propensity of the latter to opt for compatibility with dominant players as a way to reduce excess inertia will be moderated by their own ability to initiate a bandwagon of adoption (Besen and Farrell 1994).

In a similar vein, Eliashberg and Robertson (1988) contend that dominant firms tend not to signal entry because of their fear of cannibalization of existing revenue streams and risk of potential antitrust actions due to "predatory preannouncing". Preannouncing is considered to be predatory when it is alleged to occur prematurely to deter customers from purchasing competitive products or technologies available sooner from smaller firms. In industries characterized by a high level of incumbency, firms will be reluctant to preannounce due to the risk of adversely affecting sales of the existing technology (Farrell and Saloner 1986a; Gatignon and Bansal 1987). On

\footnotetext{
${ }^{4}$ But problems may occur when incumbents with large installed bases are also competing in the new technology. Several studies have shown that in such a situation, incumbents' investment efforts in the new technology will not be optimal, mainly due to inertia and the fear of cannibalizing their own revenue streams (Reinganum 1983; Ghemawat 1991).
} 
the contrary, in the case of a radical innovation in an industry characterized by new entrants, firms will be more inclined to preannounce due to the lack of exposure to potential cannibalization and to the low risk of competitors' reactions. However, new entrants' benefits from preannouncing will be moderated by the high probability that incumbents will match the signal, since this increases with a firm's commitment to a product category (Robertson, Eliashberg and Rymon 1995).

Finally, in industries characterized by a high level of incumbency, firms will be more inclined to develop internally the appropriate skills and expertise to market a radical innovation. The rationale for this belief is based on a transaction cost argument. More specifically, we contend that a firm's propensity to acquire externally vital assets to market a radical innovation is negatively related to its previous investments in the product category. This logic is supported by various studies in the context of channel integration (Anderson 1985), international distribution (Klein, Frazier and Roth 1990), and R\&D alliance formation (Robertson and Gatignon 1998). Conversely, when the industry consists primarily of new entrants, the incentives to acquire co-specialized assets externally will dominate in order to penetrate the market rapidly.

P4 The higher the level of incumbency, the greater the likelihood of (1) a penetration strategy and (2) compatibility, and the lower the likelihood of (3) preannouncing and (4) the use of an external route to market to reduce time-to takeoff.

\section{Sources of Advantage}

Sources of advantage are firms' characteristics that allow the firm to develop positional advantages (Day and Wensley 1988; Green, Barclay, and Ryans 1995). They include superior resources (e.g., reputation) and positional advantages acquired through previous moves (e.g., pioneering advantage). We contend that these factors affect the selection of an entry strategy to achieve rapid sales takeoff.

\section{Reputation}

The literature in economics and management views reputation as an asset that has a potentially positive influence on future rents (Shapiro 1982; Wilson 1985) and which can provide a firm with a sustainable competitive advantage (Hunt and Morgan 1995). A firm's reputation expresses the market perception of the level 
of esteem held by an organization in the eyes of its constituents. Although a firm's reputation can be related to specific dimensions (e.g., product quality), research indicates that reputation tends to refer to the global evaluation of an organization (Weiss, Anderson and Macinnis 1999). Relatedly, in the consumer behavior literature, reputation is treated as a component of source credibility (Goldberg and Hartwick 1990), where an advertiser's reputation relates to the perceived truthfulness of its advertising.

Firm reputation also has been treated as an indicator of a firm's market commitment and its willingness to defend. For this reason reputation-building behavior is strategically important (Weigelt and Camerer 1988) and has been discussed in the literature in conjunction with entry deterrence (see for example, Milgrom and Roberts 1982; Weigelt and Camerer 1988; Scherer and Ross 1990). However, in this study, we focus our attention on how a firm's reputational stock influences its strategy instead of looking at reputation-building behavior. Accordingly, in the case of a firm launching a radical innovation, reputation can be seen as the present effect of its previous conduct in the product category or in related product categories. The level of reputation acquired in different product categories is particularly relevant when firms launching radical innovations come from a range of industries and converge to form a new industry (e.g., telecommunications, computing and media/entertainment that are competing in the multimedia industry). If a firm has a "good" reputation, it is able to capitalize on this asset and it will be able to influence positively the expectations of potential users as in the case of AOL (Shapiro 1983).

Radical innovations, characterized by high uncertainty, may be subject to reputational effects of the supplier. In economics, earlier work has shown that reputation at the brand level works as a mechanism for ensuring quality to the consumer (Hayek 1948). Similarly reputation will influence consumers' expectations about new technologies and, therefore, affect their quality perception (Nelson 1970; Margulies 1977; Shapiro 1982, 1983). Hence, if there are uncertainties about the innovation's quality or performance, a good reputation mitigates those uncertainties and may foster a faster takeoff (Montgomery 1975; Robertson and Gatignon 1986).

All other things being equal, therefore, the high reputation firm has less incentive to engage in an aggressive entry strategy. It can borrow from its reputational stock to encourage initial adoption and will be less 
inclined to engage in aggressive pricing or to make substantial resource commitments in marketing. Similarly it will rely on its reputation to enforce its own standard unilaterally, under the logic that consumers will use the reputational factor as a cue for a dominant design. This is consistent with the analytical model of Katz and Shapiro (1985), who found that high reputation firms tend to be against compatibility, whereas low reputation firms favor compatibility.

Reputation can significantly enhance the effectiveness of preannouncing, as reputation is an important means to signal sender credibility, which, in turn, affects communication effectiveness (Hovland, Janis and Kelly 1953; McGinnies 1973; Sternthal, Dholakia, and Leavitt 1978). As a result, announcements of the impending introduction of a radical innovation may be more effectively issued by a firm with a strong reputation, since customers use reputation as an estimate of private information that cannot be obtained normally (Goldberg and Hartwick 1990; Heil and Robertson 1991; Brockhoff and Rao 1993; Robertson, Eliashberg and Rymon 1995). This increases the probability of success for the preannouncement and the incentives for reputable firms to preannounce.

As Chu and Chu (1994) indicate, unknown start-ups can rarely make effective use of tools that the theoretical literature has shown to increase customer perception of product quality (e.g., advertising, brand names and warranties) and, therefore they may be inclined to seek the reputation umbrella of a well established competitor. Our argument is that the lower the level of a firm's reputation, the lower its ability to signal quality and technological superiority. Under these circumstances, manufacturers of radical innovations may decide to acquire complementary assets including reputation (Teece 1992) by commercializing their product through existing and reputable partners.

P5 The higher a firm's reputation, the lower the likelihood of (1) penetration strategies, (2) product compatibility, and (3) the use of an external route to market but the greater the likelihood of (4) preannouncing to reduce time-to-takeoff.

\section{Order of entry}

The reader will be familiar with the rich literature within marketing, economics, and strategy regarding order of entry effects. The general proposition emanating from research in economics is that first movers will 
have lasting advantages (Bain 1956; Bond and Lean 1977; Schmalensee 1982). This has been confirmed in a number of marketing studies (Robinson and Fornell 1985; Urban et al. 1986; Robinson 1988b), and the mechanisms whereby pioneer advantage is derived have been explored. However, results are not unequivocable (Moore, Boulding, and Goodstein 1991). In particular, it has been argued that first movers tend to have higher returns but their order of entry is also related to higher risk of failure (Kalyanaram and Urban 1992). Indeed, research on first mover advantages has been shown to be subject to a number of limitations and potential biases (Kerin, Varadarajan, and Peterson 1992)

As related to radical innovations, it may be that early entrance is less important, since the prospect of market share advantage for a first entry is moderated by the high level of uncertainty of market acceptance (Kalyanaram and Urban 1992). By contrast, while acting in a less uncertain market, later entrants can take strategic actions to reduce the market share penalty due to their delayed entry. In their historical analysis of the cement, glass and minicomputer industries, Anderson and Tushman (1990) found that the pioneering technology was never dominant.

In this study, we treat the entry decision as exogenous and we contend that order of entry can help to explain a firm's launch strategy for a radical innovation. The first mover of a radical innovation will have the option of skimming vs. penetration as influenced by factors already specified, such as externalities and appropriability. However, theoretical (Schmalensee 1982) and empirical research suggests that pioneers tend to charge higher rather than lower prices (Robinson and Fornell 1985; Robinson 1988b; Lambkin 1988). This might be due to a combination of lower levels of price sensitivity among consumer innovators and the initial power of the first mover. On the contrary, later entrants may seek differentiation from the pioneer as their entry strategy but are quite likely to pursue a penetration price strategy backed by intense advertising expenditures (Urban et al. 1986; Lilien and Yoon 1990). The basis for this is that the later entrant may gain advantage from lower imitation costs, free-rider effects, scope economies, and benefits by learning from the pioneer's mistakes (Lieberman and Montgomery 1988; Kerin, Varadarajan and Peterson 1992). 
The more prevalent pattern as industries evolve is that later entrants tend to enter based on a penetration strategy (Lambkin 1988). Recent studies have shown that order of entry influences how entry should be pursued. In particular, Bowman and Gatignon (1996) document that marketing mix responsiveness diminishes with order of entry. As a result followers need to compensate for not being the first with their marketing mix decisions, including pricing.

The first mover will have a tendency to seek market pioneer advantages and to ignore product compatibility. By influencing the way new product category attributes are defined, the pioneer tends to become associated with a product category (Carpenter and Nakamoto 1989). This suggests that the first mover will be more inclined to pursue the advantages derived from its leading position rather than to try to achieve compatibility with actual and potential new entrants. By contrast, later entrants will tend to take advantage of the reduced market uncertainty and, therefore, to accept the emerging dominant design. In order to seek advantage, they will attempt to compete on alternative dimensions, especially price and positioning (Lieberman and Montgomery 1988). First movers may or may not preannounce based on their assessment of the competitive cueing risks compared to switching and learning cost reductions (Eliashberg and Robertson 1988). For later entrants, however, there will be a strong tendency to preannounce in order to freeze consumer demand until the late entrant is represented on the market (Porter 1980). This has been demonstrated recently in the software industry and "vaporware" has become a common phenomenon -- new products that are announced, yet whose very existence is questionable, or at least, questionable in the time frame suggested by the preannouncement.

As alluded to earlier, later entrants are faced with a lower degree of demand uncertainty, which facilitates the formation of contractual or collaborative links with external sources. This is due to the fact that the transaction costs to specify, monitor, and enforce a workable contract decline when the uncertainty concerning market acceptance and market growth decreases (Balakrishnan and Wernerfelt 1986; Klein, Frazier and Roth 1990). Empirical evidence supports this hypothesis that later entrants externally acquire the resources necessary to enter and quickly gain market share (Robinson, Fornell and Sullivan 1992). For instance, Glaxo utilized a great 
number of marketing alliances as it introduced Zantac as a late entrant to Smith-Kline's Tagamet in the anti-ulcer market.

P6 The earlier a firm's entry, the lower the likelihood of (1) a penetration strategy (2) compatibility to reduce time to-takeoff, (3) preannouncing to reduce time-to-takeoff, and (4) the use of an external route to market to reduce take-off.

\section{MANAGEMENT AND RESEARCHER IMPLICATIONS}

The conceptualization suggested has its focus on a set of strategic actions that the firm can undertake to achieve faster takeoff. Unlike most research and theory in diffusion, we are concerned only with the component of the diffusion curve before takeoff occurs.

Managers launching radical innovations face an interesting challenge in managing both type 1 and type 2 errors. They run the risk of investing prematurely in technologies and not receiving a reasonable return on their investment. But they also run the risk of being left behind if they under-invest in a technology that takes off rapidly.

Radical innovations span a considerable range of takeoff times. Although the average is 10 to 12 years (Lehmann 1994; Tellis 1994), there is considerable variation. The Sony Walkman is considered to have achieved takeoff within one year, whereas other technologies, such as ATMs and VCRs appear to have taken a full decade or more. Golder and Tellis (1997) also observe that time-to-takeoff is decreasing for more recent consumer durables. ${ }^{5}$ Interestingly, in many cases the initial application is also not the application, which eventually finds market success (Moore 1994), such as VCR which were originally positioned on their recording capabilities rather than playback capabilities.

There could be arguments that slower takeoff is advantageous for the firm -- less up-front investment, less risk of technical problems etc. The position of the monopolist might also favor retarding conversion to the new technology in favor of the earnings' stream for the existing installed base. Nevertheless, most managers favor rapid acceleration in order to achieve a quicker return on investment, to achieve experience curve effects,

\footnotetext{
${ }^{5}$ Time-to-takeoff for pre-World War II categories is 18 years, but only 6 years for post-World War II categories.
} 
to build share and reputation, and to block competitive entry (Robertson 1993). Thus, our purpose has been to discuss strategies for accelerating takeoff and we recognize our pro-innovation bias. However, opportunity windows for technology may open and close quickly, thus necessitating a focus on rapid acceleration.

The paper has suggested that takeoff time can be reduced if an industry participant pursues a composite of strategic actions. These are: (1) pursue a penetration strategy, (2) achieve product compatibility, (3) preannounce new products, and (4) use an external route to market. These strategies are instrumental at the customer level in encouraging more rapid adoption. They act as levers on the chief factors that determine consumer adoption which are awareness, willingness to pay, and availability.

Although managers may recognize the logic of these strategies and their effect on adoption behavior, their value and their particular effect is a function of a number of factors. In particular, the appropriateness of these strategies to accelerate adoption depends on the characteristics of the technology, the industry, and the firm's sources of advantage. We have generated a set of hypotheses as summarized in Table 2, which probes the likelihood of the firm pursuing a particular strategy dependent on each characteristic.

- insert Table 2 about here -

In summary, we would suggest that the manager should consider the following strategies under the following conditions:

- $\quad$ Penetration strategy (vs. a skimming strategy) under conditions of high network externalities, high appropriability, a high level of industry incumbency, low firm reputation, and late market entry.

- $\quad$ Product compatibility under conditions of high network externalities, low appropriability, low industry concentration, a high level of industry incumbency, low firm reputation, and late market entry.

- $\quad$ Preannouncing of technology under conditions of high network externalities, high appropriability, low industry concentration, low level of industry incumbency, high firm reputation, and late market entry.

- External routes to market under conditions of high network externalities, high appropriability, low industry concentration, low level of industry incumbency, low firm reputation, and late market entry. 
The reader will be aware that there are limitations to these suggestions. In particular, the empirical base to support these propositions is not always extensive and much of the literature is based on game theory or on limited data sets and surveys.

Researchers may find the propositional inventory to be a useful research agenda. Significant contribution could be made to the marketing literature by focusing on radical innovations, since they represent an important management topic which has been underrepresented in empirical research within our field. In particular, research focused on time-to-takeoff could contribute to both the behavioral and modeling literatures on diffusion. This is a rich research topic and may require innovative empirical approaches because of the difficulties of conducting research before actual market data exist and when market acceptance has not yet been achieved. However, effort should be directed to collect data from launch and to examine the interaction between marketing activities and environmental covariates to model the effectiveness of different entry strategies in various competitive and technological conditions. This could also imply combining different data methodologies, such as experimental design, surveys and simulation. In order to foster this process Table 1 provides a summary of the operational definitions of the key variables examined in this study that could be a starting point for future empirical analysis.

In particular, we suggest that future research could utilize experimental designs to highlight the causal links between entry strategy and competitive and technological scenarios prior to takeoff. Although sacrificing some degree of realism, these methods permit the isolation of the main theoretical variables and the assessment of how the competitive and technological environments affect managerial judgments concerning launch strategies. Relatedly, some of the propositions we developed could be tested with a cross section of radical innovations launched by different organizations in different industries. Obviously, the level of complexity of the required data makes this topic particularly difficult to explore. As a result, the experimental approach could be extended by using computer based simulation to assess which contingencies lead to what form of market conduct and how this affects time-to-takeoff. The use of simulation as a tool for competitive-strategy decisions has been suggested by Reibstein and Chussil (1997) and it has also been recommended as a means for developing theories concerning research issues that "resist empirical analysis" (Lomi and Larsen 1995, p.1294). 


\section{Table 1}

\section{CONCEPTUAL AND OPERATIONAL DEFINITIONS OF KEY VARIABLES}

\begin{tabular}{|c|c|c|c|}
\hline Variable & Conceptual Definition & Operational Definition & Relevant Literature \\
\hline TIME-TO-TAKEOFF & $\begin{array}{l}\text { Diffusion phase from } \\
\text { introduction to growth. }\end{array}$ & $\begin{array}{l}\text { Takeoff is found to correspond to } \\
\text { the first year in which a } \\
\text { product's relative growth crosses } \\
\text { the threshold for takeoff. (Golder } \\
\& \text { Tellis 1997) }\end{array}$ & $\begin{array}{l}\text { Rogers 1995; Muller, Mahajan } \\
\text { and Srivastava 1990, Tellis } \\
\text { 1994, Golder \& Tellis } 1997 .\end{array}$ \\
\hline \multicolumn{4}{|l|}{ STRATEGIC ACTIONS } \\
\hline PENETRATION STRATEGY & $\begin{array}{l}\text { An aggressive pricing, } \\
\text { promotion and distribution } \\
\text { strategy to achieve rapid } \\
\text { market acceptance. }\end{array}$ & $\begin{array}{l}\text { Price and marketing expenditure } \\
\text { levels relative to similar } \\
\text { technologies at market } \\
\text { introduction. }\end{array}$ & $\begin{array}{l}\text { Bain 1956; Robinson \& } \\
\text { Lakhani 1975; Dolan \& } \\
\text { Jeuland 1981; Kalish 1988; } \\
\text { Horsky 1990. }\end{array}$ \\
\hline COMPATIBILITY & $\begin{array}{l}\text { Whether the firm chooses to } \\
\text { make its technology } \\
\text { compatible with an existing } \\
\text { industry standard. }\end{array}$ & $\begin{array}{l}\text { Level of customer switching } \\
\text { costs. }\end{array}$ & Katz and Shapiro 1985, 1986a. \\
\hline PREANNOUNCING & $\begin{array}{l}\text { An announcement or move } \\
\text { that precedes an actual new } \\
\text { product introduction. }\end{array}$ & $\begin{array}{l}\text { Formal deliberate } \\
\text { communications in advance of } \\
\text { when the product or service is } \\
\text { actually introduced or test } \\
\text { marketed (Robertson \& } \\
\text { Eliashberg 1988). }\end{array}$ & $\begin{array}{l}\text { Robertson \& Eliashberg 1988; } \\
\text { Robertson, Eliashberg and } \\
\text { Rymon } 1995 .\end{array}$ \\
\hline $\begin{array}{l}\text { EXTERNAL ROUTES TO MARKET: } \\
\text { MARKETING ALLIANCES }\end{array}$ & $\begin{array}{l}\text { A contractual relationship } \\
\text { between the technology } \\
\text { provider and an independent } \\
\text { entity for the purpose of } \\
\text { achieving market access. }\end{array}$ & $\begin{array}{l}\text { Sample operationalization: A } \\
\text { marketing alliance meets the } \\
\text { following criteria: joint } \\
\text { marketing of } 2 \text { complementary } \\
\text { products from two different firms } \\
\text { and written agreements } \\
\text { governing the relationship. } \\
\text { (Bucklin \& Sengupta 1992). }\end{array}$ & $\begin{array}{l}\text { Pisano, Russo \& Teece 1988; } \\
\text { Achrol, Scheer \& Stern 1990; } \\
\text { Bucklin \& Sengupta 1992; } \\
\text { Teece } 1992 .\end{array}$ \\
\hline \multicolumn{4}{|l|}{ TECHNOLOGY CHARACTERISTICS } \\
\hline NETWORK EXTERNALITIES & $\begin{array}{l}\text { The utility that a given user } \\
\text { derives from a good depends } \\
\text { upon the number of other users } \\
\text { who are in the same } \\
\text { "network." }\end{array}$ & $\begin{array}{l}\text { The additional premium that } \\
\text { consumers are willing to pay to } \\
\text { have a product compatible to an } \\
\text { existing installed base (Gandal } \\
\text { 1994). }\end{array}$ & $\begin{array}{l}\text { Katz and Shapiro 1985, 1986a, } \\
\text { 1986b; Farrell \& Saloner 1985, } \\
\text { 1986a, 1986b; Choi 1994. }\end{array}$ \\
\hline APPROPRIABILITY & $\begin{array}{l}\text { The attributes of the } \\
\text { innovation that allow the firm } \\
\text { to capture profits from } \\
\text { innovative activity. }\end{array}$ & $\begin{array}{l}\text { The firm's ability to protect its } \\
\text { innovation because knowledge is } \\
\text { tacit or legal protection exists } \\
\text { (Teece 1986). }\end{array}$ & $\begin{array}{l}\text { Teece 1988; Geroski 1995; } \\
\text { Kotabe, Sahay \& Aulakh 1996; } \\
\text { Anderson \& Coughlan 1987; } \\
\text { Robertson, Eliashberg \& } \\
\text { Rymon 1995. } \\
\end{array}$ \\
\hline \multicolumn{4}{|l|}{ INDUSTRY CHARACTERISTICS } \\
\hline INDUSTRY CONCENTRATION & $\begin{array}{l}\text { Industry concentration reflects } \\
\text { the number and the size of the } \\
\text { firms operating in an industry. }\end{array}$ & $\begin{array}{l}\text { Concentration ratios (e.g. market } \\
\text { share of the three largest } \\
\text { competitors in the market, } \\
\text { Bowman \& Gatignon 1995); } \\
\text { Herdindahl-Hirshman Index } \\
\text { (Scherer \& Ross 1990). }\end{array}$ & $\begin{array}{l}\text { Scherer and Ross 1990; } \\
\text { Bowman and Gatignon 1995; } \\
\text { Robinson 1988a. }\end{array}$ \\
\hline LEVEL OF INCUMBENCY & $\begin{array}{l}\text { Level of incumbency reflects } \\
\text { the proportion of firms } \\
\text { deriving a rent from their own } \\
\text { experience in the industry and } \\
\text { their installed base. }\end{array}$ & $\begin{array}{l}\text { Extent to which firms } \\
\text { participating in a new } \\
\text { technology also participated in } \\
\text { the previous technology. }\end{array}$ & $\begin{array}{l}\text { Gilbert 1989; Brynjolfsson \& } \\
\text { Kemerer } 1996 .\end{array}$ \\
\hline \multicolumn{4}{|l|}{ FIRM CHARACTERISTICS } \\
\hline ORDER OF ENTRY & $\begin{array}{l}\text { The order of entry of a firm } \\
\text { into a new product category. }\end{array}$ & $\begin{array}{l}\text { Order of entry of the } n t h \text { brand in } \\
\text { a category (Urban et al. 1986). }\end{array}$ & $\begin{array}{l}\text { Bond \& Lean 1977; } \\
\text { Schmalensee 1982; Robinson } \\
\text { \& Fornell 1985; Urban et al. } \\
\text { 1986, Robinson 1988b, Kerin, } \\
\text { Varadarajan \& Peterson 1992; } \\
\text { Bowman \& Gatignon } 1996 .\end{array}$ \\
\hline REPUTATION & $\begin{array}{l}\text { An asset that has a potentially } \\
\text { positive influence on future } \\
\text { rents. }\end{array}$ & $\begin{array}{l}\text { The extent to which customers } \\
\text { perceive new product providers } \\
\text { as highly regarded, professional, } \\
\text { successful, well-established and }\end{array}$ & $\begin{array}{l}\text { Shapiro 1993; Robertson \& } \\
\text { Gatignon 1986; Wernerfelt } \\
\text { 1988; Goldberg \& Hartwick } \\
1990\end{array}$ \\
\hline
\end{tabular}




\begin{tabular}{|l|l|l|l||}
\hline & & $\begin{array}{l}\text { stable (Weiss, Anderson \& } \\
\text { Maclnnis 1999). }\end{array}$ & \\
\hline
\end{tabular}


Table 2

THE PROPOSITIONAL INVENTORY

\section{Likelihood of Strategic Action}

\begin{tabular}{ccccc} 
& Penetration & Product & & External \\
Proposition & Strategy & Compatibility & Preannouncing & $\begin{array}{l}\text { Route to } \\
\text { Market }\end{array}$ \\
\hline
\end{tabular}

\section{TECHNOLOGY}

\section{CHARACTERISTICS}

- Network Externalities

P1

- Appropriability

COMPETITIVE

ENVIRONMENT

- Industry Concentration

- Level of Incumbency

SOURCE OF

ADVANTAGE

- Reputation

- Order of Entry
$\mathrm{P} 2$

P3

$\mathrm{P} 4$

P5

P6
$+$

$+$

$*$

$+$

$+$

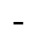

$+$

$-$
$+$

* No proposition provided. 


\section{References}

Achrol, R.S., L.K. Scheer, and L. W. Stern, 1990. Designing Successful Transorganizational Marketing Alliances. MSI, Report No. 90-118, Cambridge, MA: Marketing Science Institute.

Agrawal, R. and B.L. Bayus, 2000. The Market Evolution and Take-Off of Product Innovations. Working Paper (July).

Anderson, E., 1985. The Salesperson as Outside Agent or Employee: A Transaction Cost Analysis. Marketing Science, 4 (3), 234-54.

and A. Coughlan, 1987. International Market Entry and Expansion via Independent or Integrated Channels of Distribution. Journal of Marketing, 51 (1), 71-82.

Anderson, P. and M.L. Tushman, 1990. Technological Discontinuities and Dominant Designs: A Cyclical Model of Technological Change. Administrative Science Quarterly, 35 (4), 604-33.

Arthur, B.W., 1989. Competing Technologies, Increasing Returns, and Lock-in by Historical Events. The Economic Journal, 99 (394), 116-31.

Axelrod, R. et al., 1995. Coalition Formation in Standard-Setting Alliances. Management Science, 41 (9), 1493508.

Bain, J.S., 1956. Barriers to New Competition. Cambridge, MA: Harvard University Press.

Balakrishnan, S. and B. Wernerfelt, 1986. Technological Change, Competition and Vertical Integration, Strategic Management Journal, 7 (4), 347-59.

Bass, F.M., 1969. A New Product Growth Model for Consumer Durables. Management Science, 15 (1), 215-27.

Bayus, B.L., S. Jain, and A. Rao, 1997. Is it Real or Is it Vaporware: An Analysis of Preannaouncements in the Software Industry, unpublished working paper, Kenan-Flagler Business School, University of North-Carolina.

Besen, S.M. and J. Farrell, 1994. Choosing How to Compete: Strategies and Tactics in Standardization. Journal of Economic Perspectives, 8 (2), 117-31.

Bond, R.S. and D. Lean, 1977. Sales, Promotion, and Product Differentiation in Two Prescription Drug Markets, Washington, DC: Federal Trade Commission.

Bowman, D. and H. Gatignon, 1995. Determinants of Competitor Response Time to a New Product Introduction. Journal of Marketing Research, 32 (1), 42-53.

and 1996. Order of Entry as a Moderator of the Effect of the Marketing Mix on Market Share, Marketing Science, 15 (3), 222-42.

Brockhoff, K.K. and V.R. Rao, 1993. Toward a Demand Forecasting Model for Preannounced New Technological Products. Journal of Engineering and Technology Management, 10 (3), 211-28.

Brown, L.A., 1981. Innovation Diffusion: A New Perspective. New York: Methuen. 
Brynjolfsson, E. and C.F. Kemerer, 1996. Network Externalities in Microcomputer Software: An Econometric Analysis. Management Science, 42 (12), 1627-909.

Bucklin, L.P. and S. Sengupta, 1992. Organizing Successful Co-Marketing Alliances. Journal of Marketing, 57 (2), 32-46.

Cabral, L., 1990. On The Adoption of Innovations with 'Network' Externalities. Mathematical Social Science, 19 (3), 299-308.

, D. Salant, and G. Woroch, 1999. Monopoly Pricing with Network Externalities. International Journal of Industrial Organization, 17 (2) 199-214.

Cestre, G. and R.Y. Darmon, 1998. Assessing Consumer Preferences in the Context of New Product Diffusion. International Journal of Research in Marketing, 15 (2), 123-35.

Chandy, R.K. and G. Tellis, 1998. Organizing for Radical Product Innovation: The Overlooked Role of Willingness to Cannibalize. Journal of Marketing Research, 35 (3) 474-87.

Carpenter, G.S. and K. Nakamoto, 1989. Consumer Preference Formation and Pioneering Advantage. Journal of Marketing Research, 26 (3), 285-98.

Chatterjee, R. and J. Eliashberg, 1990. The Innovation Diffusion Process in a Heterogeneous Population: A Micromodeling Approach. Management Science, 36 (9), 1057-79.

Chen, M. and I.C. MacMillan, 1992. Nonresponse and Delayed Response to Competitive Moves: The Roles of Competitor Dependence and Action Irreversibility. Academy of Management Journal, 35 (3), 539-70.

Choi, J.P., 1994. Irreversible Choice of Uncertain Technologies with Network Externalities. Rand Journal of Economics, 25 (3), 382-401.

Chou, C. and O. Shy, 1990. Network Effects Without Network Externalities. International Journal of Industrial Organization, 8 (2), 259-70.

Chu, W. and W. Chu, 1994. Signaling Quality by Selling Through a Reputable Retailer: An Example of Renting the Reputation of Another Agent. Marketing Science, 13 (2), 177-89.

Cooper, A.C. and D. Schendel, 1976. Strategic Responses to Technological Threats. Business Horizons, 19 (1), 61-9.

Day, G.S. and R. Wensley, 1988. Assessing Advantage: A Framework for Diagnosing Competitive Superiority. Journal of Marketing, 52 (2), 1-20.

Dean, J., 1969. Pricing Pioneering Products. Journal of Industrial Economics, 17 (3), 165-79.

Dhebar, A., 1995. Complementarity, Compatibility, and Product Change: Breaking with the Past? Journal of Product Innovation Management, 12 (2), 136-52.

and S.S. Oren, 1986. Dynamic Nonlinear Pricing in Networks with Interdependent Demand, Operations Research, 34 (3), 384-394. 
Dolan, R.J. and A.P. Jeuland, 1981. Experience Curves and Dynamic Demand Models: Implications for Optimal Pricing Strategies. Journal of Marketing, 45 (1), 52-62.

and E. Muller, 1986. Models of New Product Diffusion: Extension to Competition against Existing and Potential Firms Over Time. In: V. Mahajan and Y. Wind (eds.), Innovation Diffusion Models of New Product Acceptance, 117-150. Cambridge, MA: Ballinger Publishing Company.

Dutta, S., O. Narasimha, and S. Rajiv, 1999. Success in High-Technology Markets: Is Marketing Capability Critical? Marketing Science 18 (4), 547-68.

Economides, N., 1996. The Economics of Networks. International Journal of Industrial Organization, 14 (6), 67399.

and C.P. Himmelberg, 1995. Critical Mass and Network Size with Application to the U.S. Fax Market. Discussion Paper EC-95-11, Stern School of Business, NYU.

and L.J. White, 1994. Networks and Compatibility: Implications for Antitrust. European Economic Review, 38 (3-4), 651-62.

Eliashberg, J. and A.P. Jeuland, 1986. The Impact of Competitive Entry in a Developing Market Upon Dynamic Pricing Strategies. Marketing Science, 5 (1), 20-36.

and T.S. Robertson, 1988. New Product Preannouncing Behavior: A Market Signaling Study. Journal of Marketing Research, 25 (3), 282-92.

Esser, P. and L. Leruth, 1989. Marketing Compatible, Yet Differentiated, Products: In Search of Competitive Equilibria When Network Externalities are at Work. International Journal of Research in Marketing, 5 (4), 251-70.

Farrell, J. and G. Saloner, 1985. Standardization, Compatibility, and Innovation. Rand Journal of Economics, 16 (1), 70-83.

and _ 1986a. Installed Base and Compatibility: Innovation, Product Preannouncements, and Predation. American Economic Review, 76 (5), 940-55. and __ 1986b. Standardization and Variety. Economics Letters, 20 (1), 71-4.

and _ 1988. Coordination Through Committees and Markets. Rand Journal of Economics, 19 (1), 235-52.

Gandal, N., 1994. Hedonic Price Indexes for Spreadsheets and an Empirical Test for Network Externalities. Rand Journal of Economics, 25 (1), 160-70.

Gatignon, H., 1984. Competition as Moderator of the Effect of Advertising on Sales. Journal of Marketing Research, 21 (4), 387-98.

and E. Anderson, 1998. Inter-Channel Competition and New Product Diffusion. Working Paper INSEAD. 
and P. Bansal, 1990. Market Entry and Defensive Strategies. In: George Day, Barton Weitz and Robin Wensley, (eds.), The Interface of Marketing and Strategy, 305-30, JAI Press.

and T.S. Robertson, 1985. A Propositional Inventory for New Diffusion Research. Journal of Consumer Research, 11 (4), 849-67.

and , 1989. Technology Diffusion: An Empirical Test of Competitive Effects. Journal of Marketing, 53 (1), 35-49. and , 1991. Innovative Decision Processes. In: T.S. Robertson and H.H. Kassarjian (eds.), Handbook of Consumer Behavior, 316-48. Englewood Cliffs, M.J.: Prentice Hall.

Geroski, P., 1995. Markets for Technology, Knowledge, Innovation and Appropriability. In: Paul Stoneman, (ed.), Handbook of the Economics of Innovation and Technological Change, 90-131. Blackwell Handbooks in Economics.

Ghemawat, P., 1991. Market Incumbency and Technological Inertia. Marketing Science, 10 (2), 161-71.

Gilbert, R. J., 1989. Mobility Barriers and the Value of Incumbency. In: Schmalensee R. and R.D. Willing, (eds.), Handbook of Industrial Organization, North Holland.

, 1992. Symposium on Compatibility: Incentives and Market Structure. The Journal of Industrial Economics, 40 (1), 1-8.

Goldberg M.E. and J. Hartwick, 1990. The Effects of Advertiser Reputation and Extremity of Advertising Claim on Advertising Effectiveness. Journal of Consumer Research, 17 (2), 172-79.

Golder P.N. and G.J. Tellis, 1997. Will It Ever Fly? Modeling the Takeoff of Really New Consumer Durables. Marketing Science 16 (3), 256-70.

Granovetter, M., 1978. Threshold Models of Collective Behavior. American Sociological Journal, 83,1420-43.

Green D.H., D.W. Barclay, and A.B. Ryans, 1995. Entry Strategy and Long-Term Performance: Conceptualization and Empirical Examination. Journal of Marketing, 59 (3), 1-16.

Griffin A. and J.R. Hauser, 1996. Integrating R\&D and Marketing: A Review and Analysis of the Literature. Journal of Product Management and Innovation. 13 (3), 191-215.

Hakansson H. and I. Snehota, 1989. No Business Is an Island: The Network Concept of Business Strategy. Scandinavian Journal of Management, 4 (3), 187-200.

Hayek, F.A., 1948. Meaning of Competition. In: Individualism and Economic Order. Chicago, IL: University Press.

Heide, J.B. and A.M. Weiss, 1995. Vendor Consideration and Switching Behavior in High-Technology Markets. Journal of Marketing, 59 (3), 30-43.

Heil, O. and T.S. Robertson, 1991. Toward a Theory of Competitive Market Signaling: A Research Agenda. Strategic Management Journal, 12 (6), 403-18. 
Horsky, D., 1990. A Diffusion Model Incorporating Product Benefits, Price, Income, and Information. Marketing Science, 9 (3), 342-65.

Hovland, C.I., I.L. Janis, and H.H. Kelley, 1953. Communication and Persuasion. New Haven, CT: Yale University Press.

Howard, J.A,1983. Marketing Theory of the Firm. Journal of Marketing, 47 (4), 90-100.

Hultink, E.J. et al., 1998. In Search of Generic Launch Strategies for New Products. International Journal of Research In Marketing, 15 (3), 269-85.

Hunt, S.D. and R. Morgan, 1995. The Comparative Advantage of Competition. Journal of Marketing, 59, (2), 115.

Jain, D. and R. Rao, 1990. Effect of Price on the Demand for Durables: Modeling, Estimation, and Findings. Journal of Business and Economic Statistics, 8 (2), 163-70.

Jensen, R., 1982. Adoption and Diffusion of an Innovation of Uncertain Profitability. Journal of Economic Theory, 27 (11), 182-93.

Jones M.J. and C.H., Mason, 1990. The Role of Distribution in the Diffusion of New Durable Consumer Products. Marketing Science Institute Report No. 90-110.

and C.J. Ritz, 1991. Incorporating Distribution into New-Product Diffusion Models. International Journal of Research in Marketing, 8 (June), 91-112.

Kalish, S., 1983. Monopolist Pricing with Dynamic Demand and Production Cost. Marketing Science, 2 (2), $135-$ 60.

, 1988. Pricing New Products from Birth to Decline: An Expository Review. In: T.M. Devinney (ed.), Issues in Pricing, 261-87. Lexington, MA: Lexington Books.

Kalyanaram, G. and G.L. Urban, 1992. Dynamic Effects of Order of Entry on Market Share, Trial Penetration, and Repeat Purchases for Frequently Purchased Consumer Goods. Marketing Science, 11 (3), 235-250.

Karshenas, M. and P.L. Stoneman, 1993. Rank, Stock, Order, and Epidemic Effects in the Diffusion of New Process Technologies: An Empirical Model. Rand Journal of Economics, 24 (1), 503-28.

Katz, M.L. and C. Shapiro, 1985. Network Externalities, Competition and Compatibility. American Economic Review, 75 (3), 424-40.

and , 1986a, Technology Adoption in the Presence of Network Externalities. Journal of Political Economy, 94 (4), 822-41. and , 1986b, Product Compatibility Choice in a Market with Technological Progress. Oxford Economics Papers, 38 (0), 146-65.

Kerin, R.A., R.P. Varadarajan, and R.A. Peterson, 1992. First Mover Advantage: A Synthesis, Conceptual Framework, and Research Propositions, Journal of Marketing, 56 (4), 33-52. 
Kim, C.W. and R. Mauborgne, 2000. Knowing a Winning Business Idea When you See One. Harvard Business Review, (September-October), 129-37.

Kim, L. and Y. Lim, 1988. Environment, Generic Strategies, and Performance in a Rapidly Developing Country: A Taxonomic Approach. Academy of Management Journal, 31 (December), 802-27.

Kim, N., E. Bridges and R.K. Srivastava, 1999. A Simultaneous Model of Innovative Product Category Sales Diffusion and Competitive Dynamics, International Journal of Research in Marketing, 16 (2), 95-111.

Klein, S., G.L. Frazier, and V.J. Roth, 1990. A Transaction Cost Analysis Model of Channel Integration in International Markets. Journal of Marketing Research, 27 (2), 196-208.

Klemperer, P., 1987. Markets with Consumer Switching Costs. Quarterly Journal of Economics, 102 (2), 375-94.

Kotabe, M., A. Sahay, and P.S. Aulakh, 1996. Emerging Role of Technology Licensing in the Development of Global Product Strategy: Conceptual Framework and Research Propositions. Journal of Marketing, 60 (1), 73-88.

Kuester, S., C. Homburg, and T.S. Robertson, 1999. Retaliatory Behavior to New Product Entry. Journal of Marketing, 63 (October), 90-106.

Lambkin, M., 1988. Order of Entry and Performance in New Markets. Strategic Management Journal, 9 (Special Issue), 127-40.

Lehmann, D. 1994. Characteristics of 'Really' New Products. In: M. Adams and J. La Cugna (eds.), And Now for Something Completely Different: "Really" New Products. MSI Report Conference Summary No 94-124.

Levin, R. et al. 1987. Appropriating the Returns from Industrial Research and Development; Comments and Discussion. Brookings Papers on Economic Activity, 3, 783-831.

Lieberman, M.B. and D.B. Montgomery, 1988. First-Mover Advantages. Strategic Management Journal, 9 (Special Issue), 41-58.

Lilien, G.L. and E. Yoon, 1990. The Timing of Competitive Entry: An Exploratory Study of the New Industrial Products. Management Science, 36 (5), 568-85.

Lomi, A and E. Larsen, 1996. Interacting Locally and Evolving Globally: A Computational Approach to the Dynamics of Organizational Populations. Academy of Management Journal, 39 (5), 1287-1321.

Mahajan, V., E. Muller, and F.M. Bass, 1990. New Product Diffusion Models in Marketing: A Review and Directions for Research. Journal of Marketing, 54 (1), 1-26.

and R. A. Peterson, 1985. Models for Innovation Diffusion. Newbury Park: Sage Publications.

Mansfield, E., 1985. How Rapidly Does New Industrial Technology Leak Out?. Journal of Industrial Economics, 34 (December), 217-23. 1986. Patents and Innovation: An Empirical Study. Management Science, 32 (2), 173-81.

Margulies, W., 1977. Make the Most of Your Corporate Identity. Harvard Business Review, 55 (4), 66-74. 
Matutes, C. and P. Regibeau, 1988. 'Mix and Match': Product Compatibility Without Network Externalities. Rand Journal of Economics, 19 (3), 221-34.

McGinnies, E., 1973. Initial Attitude, Source Credibility, and Involvement as Factors in Persuasion. Journal of Experimental Social Psychology, 9, 285-96.

Milgrom, P. and J. Roberts, 1982. Limit Pricing and Entry Under Incomplete Information. Econometrica, 50 (2), 443-59.

Montgomery, D.B., 1975. New Product Distribution: An Analysis of Supermarket Buyer Decisions. Journal of Marketing Research, 12 (3), 255-64.

Moore, W. L., 1994. What Can Be Learned from the Past. In: M. Adams and J. La Cugna, (eds.), And Now for Something Completely Different: 'Really' New Products, Marketing Science Institute Report Conference Summary No 94-124.

Moore, M.J., W. Boulding, and R.C. Goodstein, 1991. Pioneering and Market Share: Is Entry Time Endogenous and Does It Matter?. Journal of Marketing Research, 28 (1), 97-104.

Moore, M.C. and M.J. Moore, 1990. Co-operation, Hierarchy and Structure. In: B.H. Sheppard, M.H. Bazerman, and R.J. Lewicki (eds.), Research on Negotiations in Organizations, 123-48. Greenwich, CT: JAI Press.

Morris, C.R. and C.H. Ferguson, 1993. How Architecture Wins Technology Wars. Harvard Business Review, $71(3), 86-96$.

Muller, E., V. Mahajan, and R.K. Srivastava, 1990. Determination of Adopter Categories by Using Innovation Diffusion Models. Journal of Marketing Research, 27 (1), 37-50.

Nascimento, F. and W.R. Vanhonacker, 1988. Optimal Strategic Pricing of Reproducible Consumer Products. Management Science, 34 (11), 921-37.

Nelson, R.R., 1970. Information and Consumer Research. Journal of Political Economy, 78 (2), 311-29.

Padmanabhan, V., S. Rajiv, and K. Srinivasan, 1997. New Products, Upgrades and New Releases: A Rationale for Sequential Product Introduction. Journal of Marketing Research, 34 (4), 456-72.

Parson, L.J., 1975. The Product Life-Cycle and Time-Varying Advertising Elasticities. Journal of Marketing Research, 12 (4), 476.

Parker, P.M., 1992. Price Elasticity Dynamics Over the Adoption Life Cycle. Journal of Marketing Research, 29 (3), 358-67.

and H. Gatignon, 1996. Order of Entry, Trial Diffusion, and Elasticity Dynamics: An Empirical Case. Marketing Letters, 7(1), 95-109.

and R. Neelameghan, 1997. Price Elasticity Dynamics over the Product Life Cycle: A Study of Consumer Durables. Marketing Letter, 8(2), 205-216. 
Pisano, G.P., 1990. The R\&D Boundaries of the Firm: An Empirical Analysis. Administrative Science Quarterly, 35 (1), 153-76.

M.V. Russo, and D.J. Teece, 1988. Joint Venture and Collaborative Arrangements in the Telecommunications Equipment Industry. In: D. Mawoery (ed.), International Collaborative Ventures in U.S. Manufacturing, Cambridge, MA: Ballinger.

Porter, M.E., 1980. Competitive Strategy. New York: Free Press.

Rao, R. and F. Bass, 1985. Competition, Strategy and Price Dynamics: A Theoretical and Empirical Investigation. Journal of Marketing Research, 22 (3), 283-96.

Reibstein, D.J. and M. Chussil, 1997. Putting the Lesson Before the Test: Using Simulation to Analyze and Develop Competitive Strategies. In: G.S. Day and D.J. Reibstein, (eds.). Wharton on Dynamic Competitive Strategy, NY: Chichester, Wiley.

Reinganum, J.F., 1983. Uncertain Innovation and the Persistence of Monopoly. American Economic Review, 73 (4), 741-48.

Robertson, T.S., 1993. How to Reduce Market Penetration Cycle Times. Sloan Management Review, 35 (3), 87 96.

and J. Eliashberg, and T. Rymon, 1995. New Product Announcement Signals and Incumbent Reactions. Journal of Marketing, 59 (3), 1-15.

and H. Gatignon, 1986. Competitive Effects on Technology Diffusion. Journal of Marketing, 50 (3), 112.

and 1998. Technological Development Mode: A Transaction Cost Conceptualization. Strategic Management Journal, 19 (6), 515-31.

Robinson, B. and C. Lakhani, 1975. Dynamic Price Models for New-Product Planning. Management Science, 21 (6), 1113-22.

Robinson, W., 1988a. Marketing Mix Reactions to Entry. Marketing Science, 7 (3), 368-85.

, 1988b. Sources of Pioneer Advantages: The Case of Industrial Goods Industries. Journal of Marketing Research, 25 (1), 87-95.

and C. Fornell, 1985. Sources of Market Pioneer Advantages in Consumer Goods Industries. Journal of Marketing Research, 22 (3), 305-17.

and M. Sullivan, 1992. Are Market Pioneers Intrinsically Stronger than Later Entrants?. Strategic Management Journal, 13 (8), 609-624.

Rogers, E.M., 1995. Diffusion of Innovation, $4^{\text {th }}$ ed., New York: Free Press.

Rohlfs, J., 1974. A Theory of Interdependent Demand for a Communications Service. The Bell Journal of Economics and Management Science, 5 (1), 16-37. 
Saloner, G. and A. Shepard, 1995. Adoption of Technologies with Network Effects: An Empirical Examination of the Adoption of Automated Teller Machines. Rand Journal Of Economics, 26 (3), 479-501.

Scherer, F.M. and D. Ross, 1990. Industrial Market Structure and Economic Performance, $3^{\text {rd }}$ Edition, Boston, MA: Houghton Mifflin Company.

Schmalensee, R., 1982. Product Differentiation Advantages of Pioneering Brands. American Economic Review, 72 (3), 349-65.

Shapiro, C., 1982. Consumer Information, Product Quality, and Seller Reputation. The Bell Journal of Economics, $13(1), 20-35$.

1983. Premium for High Quality Products as Returns to Reputations. Quarterly Journal of Economics, 98 (4), 659-79.

Sternthal, B., Dholakia, R. and C. Leavitt, 1978. The Persuasive Effect of Source Credibility: Tests of Cognitive Response. Journal of Consumer Research, 4 (4), 252-8.

Taylor, C. and A. Silbertson, 1973. The Economic Impact of the Patent System, Cambridge: Cambridge University Press.

Teece, D.J., 1986. Profiting from Technological Innovation: Implications for Integration, Collaboration, Licensing and Public Policy. Research Policy, 15 (5), 285-305.

1988. Capturing Value from Technological Innovation: Integration, Strategic Partnering, and Licensing Decisions. Interfaces, 18 (3), 46-61.

1992. Competition, Cooperation, and Innovation: Organizational Arrangements for Regimes of Rapid Technological Progress. Journal of Economic Behavior and Organization, 18 (1), 1-25.

Tellis, G.J., 1994. Forecasting Market Opportunities: Predicting the Takeoff of New Durables. In: M. Adams and J. La Cugna, (eds.), And Now for Something Completely Different: "Really" New Products, Marketing Science Institute Report Conference Summary No 94-124.

Tripsas, M., 2000. Commercializing Emerging Technologies Through Complementary Assets. In : G.S. Day and P.J.H. Schoemaker, (eds.), Wharton on Managing Emerging Technologies, NY: Wiley.

Tushman M.L. and P. Anderson, 1986. Technological Discontinuities and Organizational Environments. Administrative Science Quarterly, 31(3), 439-465.

Urban, G. L., et al., 1986. Market Share Rewards to Pioneering Brands: An Empirical Analysis and Strategic Implications. Management Science, 32 (6), 645-59.

Wade, J., 1995. Dynamics of Organizational Communities and Technological Bandwagons: An Empirical Investigation of Community Evolution in the Microprocessor Market. Strategic Management Journal, 16 (Special Issue), 111-33.

Weigelt, K. and C. Camerer, 1988. Reputation and Corporate Strategy; A Review of Recent Theory and Applications. Strategic Management Journal, 9 (5), 443-54. 
Weiss, A.M, E. Anderson, and D.J. Macinnis, 1999. Reputation Management as a Motivation for Sales Structure Decisions. Journal of Marketing, 63 (3) 74-89.

Wernerfelt, B. 1988. Umbrella Branding as a Signal of New Product Quality: An Example of Signaling By Posting a Bond. Rand Journal of Ecomomics, 19 (3), 458-466.

Wilson, R. 1985. Reputation in Games and Markets. In: A.E. Roth (ed.), Game Theoretic Models of Bargaining, 27-62. Cambridge: University Press.

Xie, J. and M. Sirbu, 1995. Price Competition in the Presence of Positive Demand Externalities. Management Science, 41 (5), 909-26.

Xuereb, J.-M. and H. Gatignon, 1997. Strategic Orientation of the Firm and New Product Performance. Journal of Marketing Research, 34 (1), 77-90. 
FIGURE 1

EXAMPLES OF TIME-TO-TAKE-OFF

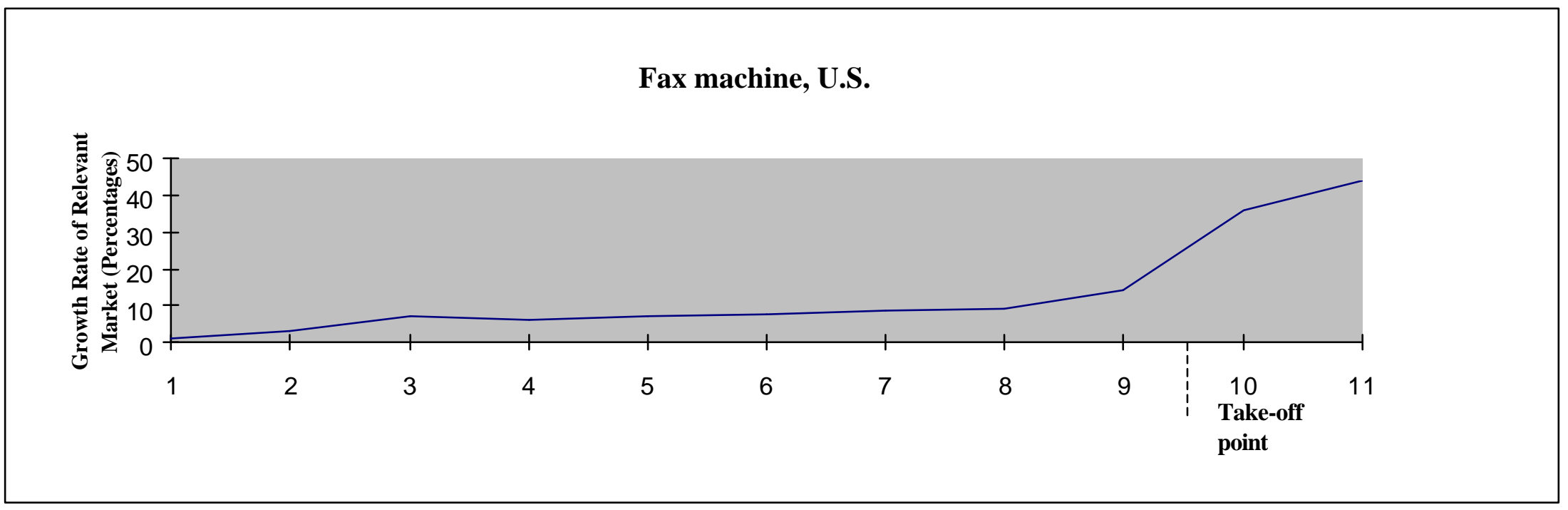

Source: Economides and Himmelberg 1995

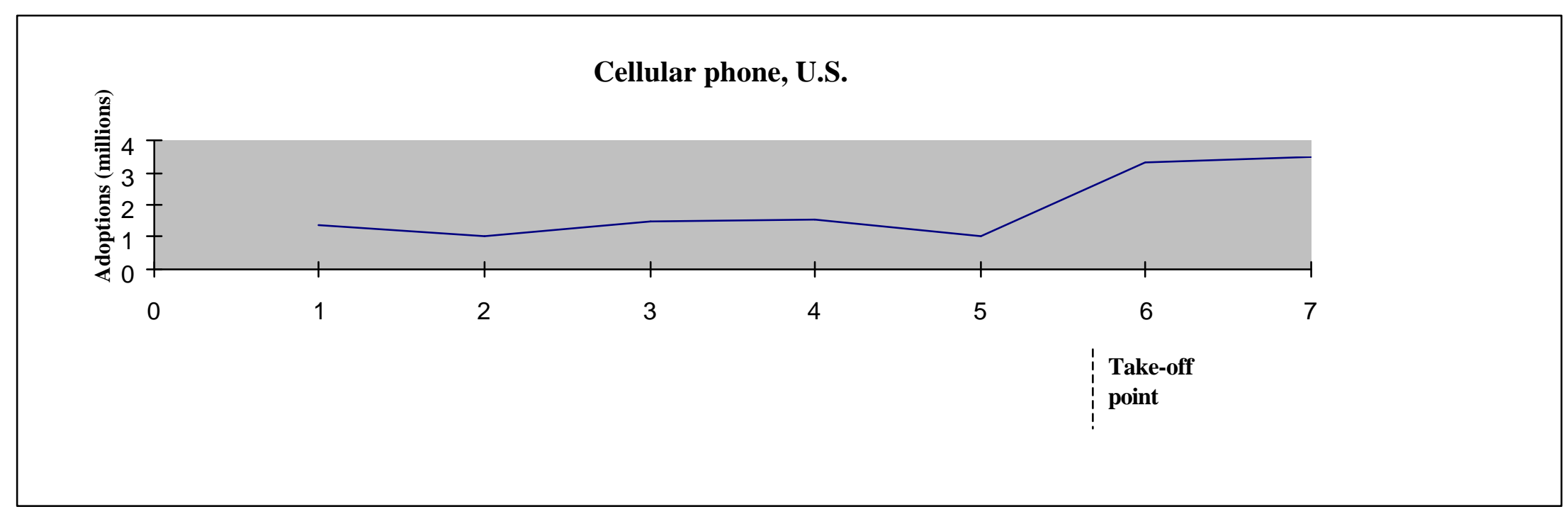

Source: Wall Street Journal 
Figure 2

CONCEPTUAL MODEL OF TIME-TO-TAKE-OFF

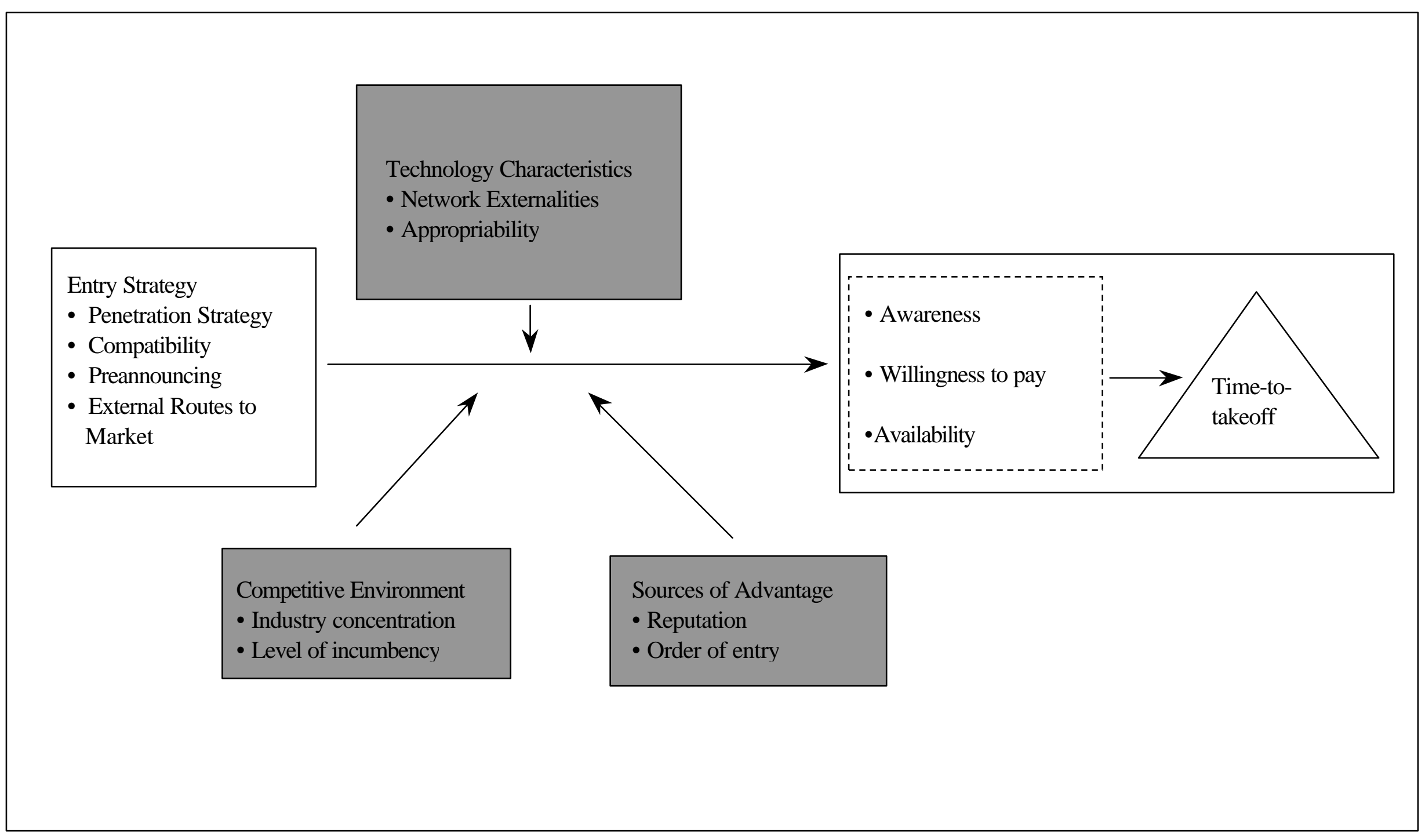

